\title{
GIBSONNEMA NOM. N., A NEW NAME FOR THE NEMATODE GENUS PARASEURATOIDES MORAVEC, SALGADO-MALDONADO ET AGUILAR- AGUILAR, 2002
}

\author{
František Moravec ${ }^{1}$, Guillermo Salgado-Maldonado ${ }^{2}$ and Rogelio Aguilar-Aguilar ${ }^{2}$ \\ ${ }^{1}$ Institute of Parasitology, Academy of Sciences of the Czech Republic, Branišovská 31, 37005 České Budějovice, Czech \\ Republic; \\ ${ }^{2}$ Institute of Biology, National Autonomous University of Mexico, A.P. 70-153, 04510 Mexico, D.F., Mexico
}

We have found that the generic name Paraseuratoides Moravec, Salgado-Maldonado et Aguilar-Aguilar, 2002 is a junior homonym to Paraseuratoides Wang, 1984. Therefore, a new name, Gibsonnema nom. n., is proposed to replace it (the new genus is named in honour of David I. Gibson, a wellknown English helminthologist).

These two genera are monotypic, belonging to the seuratoid family Quimperiidae Gendre, 1928, and both their type species are parasitic in swamp-eels (Synbranchidae, Synbranchiformes). However, they are well separated morphologically. In contrast to Gibsonnema, the genus Paraseuratoides is characterised mainly by a toothless buccal

Received 29 July 2002 cavity, a bulbously inflated anterior end of the oesophagus and the presence of caudal alae in the male.

\section{References}

Moravec F., Salgado-Maldonado G., Aguilar-Aguilar R. 2002: Two new nematodes, Paraseuratoi-des ophisterni gen. et sp. n. (Quimperiidae) and Philo-metra ophisterni sp. n. (Philometridae), from the swamp-eel Ophisternon aenigmaticum in Mexico. Folia Parasitol. 49: 109-117.

Wang P.-q. 1984: Some nematodes of fishes from Fujian Province, China. Acta Zootaxon. Sin. 9: 228-237. (In Chinese, Engl. summary.)

Accepted 30 July 2002 